\title{
IN WHOSE INTEREST? THE NEED FOR CONSISTENCY IN TO WHOM, AND ABOUT WHOM, AUSTRALIAN PUBLIC INTEREST WHISTLEBLOWERS CAN MAKE Protected Disclosures
}

\author{
PAUL LATIMER* AND A J BROWN**
}

[Since the 1990s Australia's nine jurisdictions have passed (or, in the case of the Northern Territory, proposed to pass) public sector whistleblower legislation. The legislation, which reflects different political origins and legislative aims, is not consistent in many respects and there are few common tests across the jurisdictions. This article analyses two issues - who the Australian whistleblower can disclose to, and who the whistleblower can make protected disclosures about. The examination of these issues indicates inconsistencies in the public law whistleblower laws enacted since the 1990s. This inconsistency is not sensible in Australia's national economy, where an employee in one State can make a protected disclosure, but an employee in another cannot make the same disclosure. This article supports the election commitment of the Rudd federal government in 2007 to introduce best practice federal whistleblowing legislation which will hopefully overcome shortcomings analysed in this article.]

* BA, DipEd (UNSW), LLB, LLM (Syd), Barrister (NSW), Barrister and Solicitor (Vic), Associate Professor, Department of Business Law and Taxation, Monash University.

** BA, LLB (UNSW), GradDipLegalPrac (ANU), PhD (Griffith),

Barrister (Qld), Barrister and Solicitor (Federal Court), Senior Research Fellow, Socio-Legal Research Centre, Griffith Law School, Griffith University; Project Leader, 'Whistling While They Work', Australian Research Council Linkage Project (LP0560303). 


\section{AUSTRALIAN WHISTLEBLOWERS LEGISLATION}

Whistleblower legislation has been passed around the world in recent years to protect whistleblowers in the public interest. Some of this builds on existing disclosure principles in the common law such as those regarding accountants, ${ }^{1}$ bankers ${ }^{2}$ and others in the financial sector. ${ }^{3}$ In addition, whistleblower protection has been introduced into Australian corporations law ${ }^{4}$ and workplace relations law. ${ }^{5}$

This article provides an analysis of two aspects of Australian whistleblower legislation regarding who a whistleblower can disclose to, and who the whistleblower can make protected disclosures about.

'Whistleblower' is a word which is not defined in Australian legislation, including the "whistleblower protection" legislation. Sometimes the wider expression "internal witness" and "professional reporter" is used to include whistleblowers and other employee insiders, an expression also not found in legislation. Whistleblowing is one of the options available to an employee who wishes to raise concerns about workplace wrongdoing. Whistleblowing is not based on personal grievances. It covers communications including

\footnotetext{
${ }^{1} \mathrm{~J}$ Baker Jones, 'Whistleblowing - no longer out of tune', The Australian Accountant 66:7, 57 (August 1996).

${ }^{2}$ See, eg, Tournier $v$ National Provincial and Union Bank of England [1924] 1 KB 461; J McI Walter and N Erlich, 'Confidences - bankers and customers: powers of banks to maintain secrecy and confidentiality', (1989) 63 Australian LJ 404.

${ }^{3}$ See, eg, Paul Latimer, 'Whistleblowing in the Financial Services Sector', (2002) 21

University Tasmania LR 39; Paul Latimer, 'Reporting suspicions of money laundering and 'whistleblowing': the legal and other implications for intermediaries and their advisers', (2002) 10 Journal Fin Crime 23; Paul Latimer, 'Whistleblowing in the insurance industry', (2003) 77 Australian LJ 614; Paul Latimer, 'Whistleblowing in the Financial Services Sector (Part 2)', (2004) 23 University Tas. LR 176.

${ }^{4}$ Part 9.4AAA ('Protection for whistleblowers') was introduced into the Corporations Act 2001 (Cth) by the Corporate Law Economic Reform Program (Audit Reform and Corporate Disclosure) Act 2004 (Cth). The Corporations Act now protects disclosures by an officer, or an employee of a company, and by a supplier and employee of a supplier to ASIC, the company's auditor, a director or other management, or to an authorised person (s 1317AA).

${ }^{5}$ Part 4A (ss 337A-337D) ('Protection for whistleblowers') was added to Schedule 1, Chapter 11 of the Workplace Relations Act 1996 (Cth) in 2004, two weeks after the Corporations Act amendments, by the Workplace Relations Amendment (Codifying Contempt Offences) Act 2004 (Cth) Schedule 1A (Whistleblowers), in force 13 July 2004.
} 
disclosure to managers, to those in charge of the organisation, to regulators, and ultimately to the public (via members of parliament and the media). An important definition of whistleblowing is 'disclosure by organization members (former or current) of illegal, immoral or illegitimate practices under the control of their employers, to persons or organisations that may be able to effect action., ${ }^{6}$

More fully, in the definition of Calland and Dehn: ${ }^{7}$

'Whistleblowing [is] -

[a] Bringing an activity to a sharp conclusion as if by the blast of a whistle (Oxford English Dictionary);

[b] Raising a concern about wrongdoing within an organisation or through an independent structure associated with it (UK Committee on Standards in Public Life);

[c] Giving information (usually to the authorities) about illegal or underhand practices (Chambers Dictionary);

[d] Exposing to the press a wrongdoing or cover-up in a business or government office (US, Brewers Dictionary);

[e] (origins) Police officer summoning public help to apprehend a criminal; referee stopping play after a foul in football.'

All definitions stress that whistleblowers are important because they can promote an informed society and provide an essential and valuable service to the public by exposing wrongdoing. Since an informed society is the foundation of a democratic society, an informed society should also encourage, support and protect whistleblowers. It is widely accepted that for whistleblowing to be encouraged, whistleblowers should have confidence that they will be safe if they speak up, thus providing the rationale for whistleblower protection legislation and supporting mechanisms. In economic terms, since wrongdoing diverts resources from their optimal application, encouraging and not ignoring whistleblowers can improve

${ }^{6}$ AJ Brown (ed), Whistleblowing in the Australian Public Sector, First Report of the Australian Research Council Linkage Project, Whistling While They Work:

Enhancing the Theory and Practice of Internal Witness Management in Public Sector Organisations, October 2007, 3, citing Marcia Miceli and Janet Near, 'The relationships among beliefs, organisational position, and whistleblowing status: A discriminant analysis', (1984) 27 Academy of Management Journal 687, 689.

7 Richard Calland and Guy Dehn, 'Introduction - Whistleblowing Around the World: the state of the art', in Richard Calland and Guy Dehn, eds, Whistleblowing Around the World-Law, Culture \& Practice (2004), 9. 
accountability by making wrongdoing known to the employer or to a specified authority, so that it can be overcome and resources directed back to their most efficient application.

The ideal whistleblower model protects a disclosure by a whistleblowing employee to the employer, and it promotes the internal resolution of the matter, without the employer needing to fear dismissal or discrimination. ${ }^{8}$ Best practice is therefore for the employer to bring whistleblower policy to the attention of employees, including their duty to disclose illegality, and the existence of the employer's whistleblower protection and support services. This can be by notice by the employer at the place of employment or on the relevant employment website, followed up follow-up training and information. ${ }^{9}$

Encouraging and not ignoring whistleblowers can improve accountability in government and public sector organisations by encouraging reporting of any wrongdoing in the organisation to the employer or to a specified authority.

The true value of whistleblowing is often hard to recognise within an organisation, especially at the time. Whistleblowers are often more easily seen, at least initially, as traitors rather than heroes. Seen as a traitor, a whistleblower may suffer discrimination and victimisation, further underpinning why whistleblowing legislation focuses strongly on the promotion of a culture where honest disclosures are not punished but are respected and valued, and on legal protection from reprisal, punishment or retribution. ${ }^{10}$

\footnotetext{
${ }^{8}$ For example, the Protected Disclosures Act 2000 (South Africa) s 6 (Protected disclosure to employer). In the UK, Part IVA (Protected Disclosures, ss 43A-43L) was added to the Employment Rights Act 1996 (UK) by the Public Interest Disclosure Act 1998 (UK) s 1. A 'protected disclosure' is defined in s 43B as a disclosure of information which, in the reasonable belief of the worker making the disclosure, tends to show a criminal offence, a failure to comply with legal obligations, a miscarriage of justice, a danger to an individual's health or safety, damage to the environment or concealment of information about any of these.

${ }^{9}$ For example, the London Borough of Lambeth and its Whistle Blowing Charter: 'Whistleblowing charter - Do you have concerns about what is happening at work? Then make them heard', September 2003, at http://www.lambeth.gov.uk/NR/rdonlyres/2F7FF9CD-FD28-4677-800D7E0291D98C9C/0/Lambeth_Whislte_Blowing_Charter.pdf (February 6, 2008) ${ }^{10}$ Paul Latimer, 'Whistleblowers get protection. Heroes ... or traitors?', (2006) 2 Monash Business Rev, 34.
} 


\section{Public Sector Whistleblower Protection laws}

All Australian jurisdictions - Commonwealth, states and territories - have passed (or, in the case of the Commonwealth after the election of the Rudd government and the Northern Territory, have proposed) legislation to protect public sector 'whistleblowers' and/or employees, with aims such as those indicated by the following long titles:

\begin{tabular}{|c|c|}
\hline Name & Long title $^{11}$ \\
\hline $\begin{array}{l}\text { Public Service Act } 1999 \text { (Cth), s } 16 \\
\text { (Protection for whistleblowers) }\end{array}$ & $\begin{array}{l}\text { An Act to provide for the } \\
\text { establishment and management of } \\
\text { the Australian Public Service, and } \\
\text { for other purposes }\end{array}$ \\
\hline 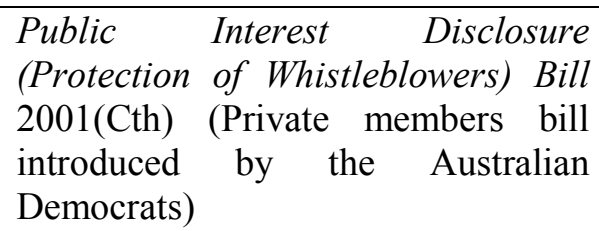 & $\begin{array}{l}\text { A Bill for an Act to encourage the } \\
\text { disclosure of conduct adverse to } \\
\text { the public interest in the public } \\
\text { sector, and for related purposes }\end{array}$ \\
\hline $\begin{array}{l}\text { Public Interest Disclosure Act } 1994 \\
\text { (ACT) }\end{array}$ & $\begin{array}{l}\text { An Act to encourage the } \\
\text { disclosure of conduct adverse to } \\
\text { the public interest in the public } \\
\text { sector, and for related purposes }\end{array}$ \\
\hline $\begin{array}{l}\text { Public Interest Disclosure Bill } 2006 \\
\text { (ACT) }\end{array}$ & $\begin{array}{l}\text { A Bill for An Act to protect people } \\
\text { who disclose certain conduct in the } \\
\text { public sector that is contrary to the } \\
\text { public interest, and for related } \\
\text { purposes }\end{array}$ \\
\hline $\begin{array}{llll}\begin{array}{l}\text { Protected } \\
\text { (NSW) }\end{array} & \text { Disclosures } & \text { Act } & 1994 \\
& & & \end{array}$ & $\begin{array}{l}\text { An Act to provide protection for } \\
\text { public officials disclosing corrupt } \\
\text { conduct, maladministration and waste } \\
\text { in the public sector; and for related } \\
\text { purposes }\end{array}$ \\
\hline
\end{tabular}

\footnotetext{
${ }^{11}$ The long title sets out the purpose of the legislation, and may be referred to as an aid in the interpretation of the legislation so long as it does not contradict clear and unambiguous language in the legislation.
} 


\begin{tabular}{|l|l|}
\hline $\begin{array}{l}\text { Public Interest Disclosure Bill 2005 } \\
\text { (NT) }\end{array}$ & $\begin{array}{l}\text { An Act about the disclosure of } \\
\text { improper conduct by public officers } \\
\text { and public bodies, and for related } \\
\text { purposes }\end{array}$ \\
\hline $\begin{array}{l}\text { Whistleblowers Protection Act 1994 } \\
\text { (Q1d) }\end{array}$ & $\begin{array}{l}\text { An Act to protect whistleblowers and } \\
\text { for other purposes }\end{array}$ \\
\hline $\begin{array}{l}\text { Whistleblowers Protection Act } 1993 \\
\text { (SA) }\end{array}$ & $\begin{array}{l}\text { An Act to protect persons disclosing } \\
\text { illegal, dangerous or improper } \\
\text { conduct; and for other purposes. }\end{array}$ \\
\hline $\begin{array}{l}\text { Public Interest Disclosures Act 2002 } \\
\text { (Tas) }\end{array}$ & $\begin{array}{l}\text { An Act to encourage and facilitate } \\
\text { disclosures of improper conduct by } \\
\text { public officers and public bodies, to } \\
\text { protect persons making those } \\
\text { disclosures and others from reprisals, } \\
\text { to provide for the matters disclosed to } \\
\text { be properly investigated and dealt } \\
\text { with and for other purposes }\end{array}$ \\
\hline $\begin{array}{l}\text { Whistleblowers Protection Act } 2001 \\
\text { (Vic) }\end{array}$ & $\begin{array}{l}\text { No long title is } \\
\text { (Cth) }{ }^{12}\end{array}$ \\
\hline $\begin{array}{l}\text { Public Interest Disclosure Act 2003 } \\
\text { (WA) }\end{array}$ & $\begin{array}{l}\text { An Act to facilitate the disclosure of } \\
\text { public interest information, to } \\
\text { provide protection for those who } \\
\text { make disclosures and for those the } \\
\text { subject of disclosures, and, in } \\
\text { consequence, to amend various Acts, } \\
\text { and for related purposes }\end{array}$ \\
\hline $\begin{array}{l}\text { A Bill for an Act to encourage and } \\
\text { facilitate the disclosure of } \\
\text { information in the public interest, by } \\
\text { protecting public officials and others } \\
\text { who make disclosures, and for related } \\
\text { purposes Bill 2007 }\end{array}$ \\
\hline
\end{tabular}

\footnotetext{
${ }^{12}$ Private member's bill introduced by Senator Murray, Australian Democrats. Second reading speech at Australian Democrat Speeches, 14 June 2006, available at $<\mathrm{http}$ //www.democrats.org.au/speeches/?speech_id=2203> at February 72008.
} 
Each is different, and there have been claims for uniformity over the years, including a 'strong case' for uniform public interest disclosure legislation made in $2007 .^{13}$

These laws facilitate public interest disclosure by aiming to protect disclosures which would otherwise breach the law such as the law of confidential information and of defamation. They also aim to provide legal remedies for whistleblowers if they suffer reprisals for making the disclosure.

Whistleblower laws overlap with existing areas of protection, such as the protection available to those who report criminal conduct, to public sector employees who report under the Ombudsman legislation of each jurisdiction, and to those who report breaches of financial administration and audit legislation. ${ }^{14}$

13 Parliament of the Commonwealth of Australia, In the Public Interest, Report of the Senate Select Committee on Public Interest Whistleblowing, August 1994; Parliament of the Commonwealth of Australia, The Public Interest Revisited, Report of the Senate Select Committee on Unresolved Whistleblower Cases, October 1995; Report on the Independent Audit into the State of Free Speech in Australia (the Moss Report) (Australia's Right to Know, 2007), Chapter 5 (Protecting Whistleblowers).

${ }^{14}$ For example, tendering irregularities, contract management, procedures for invoicing and reconciliations, outstanding deliverables, and ownership rights to contract materials.

16 This research was made possible by funding from the Australian Research Council (ARC Linkage Project LP0560303) and the various industry partners to this project, as listed on the project website

$<$ www.griffith.edu.au/centre/slrc/whistleblowing $>$. The authors thank their colleagues on the Whistling While They Work Project Team, as well as these industry partners and the participants for their assistance with this research. The findings and views expressed in this paper are those of the authors and do not necessarily represent the views of the Australian Research Council or the project industry partners. Further detail is set out in A J Brown, Public Interest Disclosure Legislation in Australia: Towards the Next Generation - An Issues Paper (Commonwealth Ombudsman, NSW Ombudsman, Queensland Ombudsman, 2006), available at $<$ www.ombudsman.gov.au/commonwealth/publish.nsf/AttachmentsByTitle/whistling_i ssues_summary/\$FILE/issues_papar_whistleblower_summary.pdf $>$ at February 6, 2008). For the draft report of the project, see Brown, above $\mathrm{n} 6$. This project has led to Senator Andrew Murray of the Australian Democrats tabling the Public Interest Disclosures Bill 2007 (Cth) in the Senate in June 2007. Peter Bennett from Whistleblowers Australia (WBA) has said that 'WBA supports the Bill as "“best practice' legislation so far, but further improvements are desirable'. 
The diversity of current whistleblower laws raises many questions, especially as there is anecdotal evidence that whistleblower reprisals are common, that legal protection is only symbolic, and that a whistleblower or witness protection scheme is a poor substitute for effective disclosure laws.

New public disclosure laws were proposed in Government information restoring trust and integrity, a policy document of the then Opposition as an election commitment of the Rudd federal government in 2007:

'Federal Labor will provide best-practice legislation to encourage and protect public interest disclosure within government to an integrity agency (for example, the Australian Federal Police, the Australian Commission for Law Enforcement Integrity or the Commonwealth Ombudsman).

Where a person has exhausted all legitimate mechanisms and avenues of complaint, and still finds that through the force of extreme circumstances they are obliged to disclose information to third parties such as journalists, protection by a court may still be provided dependent upon the circumstances.

In situations where there may be compelling reason requiring disclosure, a court will be able to weigh up all the relevant factors and balance the public interest in disclosure against any breach of confidentiality which may have occurred.

In these cases, there will be two key tests to determine when public interest disclosure will attract legal protection. Firstly, where the whistleblower has gone through the available official channels, but has not had success within a reasonable timeframe and, secondly, where the whistleblower is clearly vindicated by their disclosure' (pages 9-10).।

\section{A ARC Project - Whistling While They Work ${ }^{16}$}

The research on whistleblowers by Dr Bill De Maria in the 1990s still provides the starting point for current research. It was undertaken before the modern legislation. ${ }^{17}$ There have been other publications on whistleblowing

\footnotetext{
${ }^{17}$ In Queensland: William De Maria, Unshielding the Shadow Culture: Queensland Whistleblower Study, Result Release One (1994); William De Maria and Cyrelle Jan, Wounded Workers: Queensland Whistleblower Study, Result Release Two (1994)
} 
which have also directed public attention to the issues, ${ }^{18}$ but the comments by De Maria have never been bettered: that he had found 'nothing to celebrate' on his 'tour through the entrails of our society, except perhaps the valour of the whistleblowers who guide us into the netherworld of corruption, incompetence, cover-ups and organisational vendettas', 19 and that 'the nonsuffering' whistleblower is 'a contradiction in terms'. ${ }^{20}$ There is empirical evidence on the many reasons deterring a person whistleblowing on corruption. $^{21}$

Existing legislation should both permit and protect whistleblowers who report misconduct such as defective administration, financial mismanagement and criminal conduct (for example, theft, fraud and secret commissions). Such protection builds on the role of auditors and their protected disclosure of irregularities in tendering, contract management, procedures for invoicing and reconciliations, outstanding deliverables and ownership rights to contract materials.

This article provides a comparative analysis of two of the many issues arising from the whistleblower laws across Australia's nine Commonwealth, state and territory jurisdictions - who they can disclose to (Part III, below), and what kinds of agencies they can make disclosures about (Part IV, below). Disappointingly, this analysis demonstrates inconsistencies in whistleblower regulation, with narrow and wide approaches, with the result that an employee of the same organisation operating Australia-wide may be permitted to blow the whistle for a particular wrongdoing in one jurisdiction but not in another jurisdiction. This situation is not sensible in Australia's national economy.

After the decision of the High Court in the Workchoices case (2006), ${ }^{22}$ a uniform national approach may now be possible with one-stop

\footnotetext{
${ }^{18}$ Quentin Dempster, Whistleblowers (1997); Brian Martin, Suppression Stories (1997); William De Maria, Deadly Disclosures: Whistleblowing and the Ethical Meltdown of Australia (1999); William De Maria, 'Queensland Whistleblowing: Sterilising the Lone Crusader', (1992) 27 Aust J of Social Issues 248; William De Maria, 'Whistleblowing', (1995) 20 Alternative Law Journal 270.

${ }^{19}$ De Maria (1999), above n 17, xiii.

20 De Maria (1999), above n 17, 25.

${ }^{21}$ Lisa Zipparo, 'Factors which deter public officials from reporting corruption', (1999) 30 Crime Law \& Soc Change 274.
}

${ }^{22}$ New South Wales $v$ Commonwealth of Australia [2006] HCA 52, (2006) 81 ALJR 34 (High Court of Australia). 
Commonwealth legislation and the potential to apply Commonwealth legislation to a wide range of employers.

\section{Who can the Whistleblower Disclose to?}

There are many differences in the Australian legislation on who a whistleblower can disclose to. Most models provide for disclosure to a 'proper authority', ${ }^{23}$ a person authorised by the $\mathrm{Act}^{24}$ or an 'appropriate entity ${ }^{25}$ or public officials such as the Auditor-General, the Ombudsman, the anti-corruption authority, members of parliament and/or the police. Only in New South Wales can disclosure be made to private persons in the media. Because of the differences in the different jurisdictions, a discloser in a company operating in one jurisdiction may not be able to disclose misconduct occurring in that jurisdiction but may be able to disclose the same misconduct in another jurisdiction. This is not sensible in Australia's single national economy. There are big differences in the legislation on who is a 'public official' or equivalent to whom disclosures may be made. Best practice legislation includes a general requirement that public interest disclosures which meet the specified tests must be investigated. ${ }^{26}$

\section{A First, internal disclosure to the employer}

Whistleblowing is initially an internal employer/employee matter, so best practice should promote internal disclosure and resolution by disclosure in the first instance to the whistleblower's supervisor/manager. Only then if the matter remains unresolved should this be followed by disclosure to those in charge of the organisation, and only once all internal avenues have been

\footnotetext{
${ }^{23}$ See, eg, Public Interest Disclosure Act 2004 (ACT) s 3; Public Interest Disclosure Act 2003 (WA) s 5(3).

${ }^{24}$ See, eg, Public Interest Disclosures Act 2002 (Tas) s 7; Whistleblowers Protection Act 2001 (Vic) s 6.

${ }^{25}$ See, eg, Whistleblowers Protection Act 1994 (Q1d) s 27. ‘Appropriate entity' is defined in the Schedule 6 Dictionary as 'a public sector entity to which a public interest disclosure may be made or referred'.

${ }^{26}$ Public Service Regulations 1999 (Cth) 2.4; Public Interest Disclosure (Protection of Whistleblowers) Bill 2007 (Cth) cl 11; Public Interest Disclosure Act 2004 (ACT) s 19; Public Interest Disclosure Bill 2006 (ACT) cl 23; Public Interest Disclosure Bill 2005 (NT) s 41; Public Interest Disclosures Act 2002 (Tas) ss 39 and 63; Whistleblowers Protection Act 2001 (Vic) ss 39 (Duty to investigate) and 72 (Duty to investigate); Public Interest Disclosure Act 2003 (WA) s 8.
} 
exhausted should there be disclosure to external agencies, entities and/or regulators.

As a first step, the whistleblower should raise any concern regarding wrongdoing with the employer through the whistleblower's immediate manager or supervisor - not a colleague - orally or in writing. If a whistleblower is uncomfortable with this, the whistleblower should be encouraged to disclose higher up in the organisation, to employer representatives such as the human resources (HR) officer, the corporate complaints unit, a health and safety representative, a union official, an executive, the parent company, the employer's lawyers or external auditors, or to a commercial reporting hotline.

Whistleblower disclosure procedures should be in place. The Public Service Act 1999 (Cth) and r 2.4 of the Public Service Regulations 1999 (Cth) require agency heads to establish procedures, which are to include procedural fairness, for dealing with whistleblower reports, and to provide that Australian Public Service employees in the agency may report breaches or alleged breaches of the Code to the agency head, the Commissioner or the Merit Protection Commissioner. The employee must first report to the agency under the Code of Conduct, and only after that can the employee take the matter further and have the report referred to the Public Service Commissioner or Merit Protection Commissioner if the employee is not satisfied with the findings or in other situations, such as where it is not appropriate for the agency head to deal with the matter. ${ }^{27}$ Section 16 of the Public Service Act 1999 (Cth) prohibits victimisation of or discrimination against a public servant whistleblower.

\section{B Second, external disclosure to relevant authority}

There are many reasons why a whistleblower would prefer disclosure of wrongdoing to an external authority instead of internal disclosure. The whistleblower may not have confidence that the matter will be dealt with internally in an appropriate manner. The whistleblower may fear reprisals or negative exposure. The whistleblower may not have time to disclose

\footnotetext{
${ }^{27}$ Australian Public Service Commissioner, Annual Report 2005-2006 (2006), 112 , available at $<$ http://www.apsc.gov.au/annualreport/0506/report.pdf $>$ at February 6 2008, indicated that the Merit Protection Commissioner received five reports during 2005/2006 (four were received in 2004/2005). Issues raised included falsifying information, performance management issues and bullying and harassment.
} 
internally, especially if a serious offence is being committed or if there is an imminent risk of danger to life, health or safety or to the environment.

Whistleblower best practice should provide avenues for external disclosure, for example to an authority independent of the employer or to government agencies such as administrative agencies including a 'prescribed person'28 and other public agencies. For example, the Public Servants Disclosure Protection Act 2005 (Canada), which came into force on April 15, 2007, established the office of Public Sector Integrity Canada to receive and investigate reports of wrongdoings, to investigate them and to make recommendations to correct them. ${ }^{29}$ The Canadian Act preserves the confidentiality of the whistleblower and the persons alleged to be responsible for the wrongdoing, and protects disclosures made in accordance with the Act, so a public servant would not be protected from a disclosure which had not used the processes set out in the Act. The process should be characterised by proper process procedures and confidentiality rather than exposure.

\section{$1 \quad$ Whistleblower disclosure to the Auditor-General}

Many Australian jurisdictions specifically provide for disclosure to the Auditor-General, ${ }^{30}$ and some Auditors-General have established whistleblower guidelines. ${ }^{31}$

${ }^{28}$ Section 43F of the Public Interest Disclosure Act 1998 (UK) provides that a qualifying disclosure may be made to persons prescribed by the Secretary of State, which include:

1. Health \& Safety risks: HSE and relevant local authority

2. Utilities/Sectors: OFTEL, OFGEM, OFWAT, Rail Regulator, Charity Commission

3. Financial Services: Financial Services Authority, HM Treasury (insurance), Occupational Pensions Regulatory Authority, Serious Fraud Office

4. Tax irregularities: Inland Revenue, Customs \& Excise

5. Public finance: National Audit Office, Audit Commission, Audit Scotland

6. Company law: Department of Trade \& Industry

7. Competition \& consumer issues: Office of Fair Trading and relevant local authority.

${ }^{29}$ Public Servants Disclosure Protection Act 2005 (Canada).

${ }^{30}$ The Auditor-General is a 'proper authority' under the Public Interest Disclosure Act 1994 (ACT) s 13 and under the Public Interest Disclosure Act 2003 (WA) s 5(3)(b); an 'appropriate authority' in the Whistleblowers Protection Act 1993 (SA) s 5(4)(c)), and 
Anti-corruption bodies exist in several Australian jurisdictions, and are a natural place for whistleblowers to report to. ${ }^{32}$ For example, NSW provides for whistleblower disclosure to the Independent Commission Against Corruption and the Police Integrity Commission. ${ }^{33}$

\section{$3 \quad$ Whistleblower disclosure to journalists}

The role of the media to inform, educate and entertain is a good foundation for supporting whistleblower disclosure to journalists. It confirms the theory of the media as the fourth branch of government. Discussion in the media to draw attention to wrongdoing is the most public way for a whistleblower to make dislosure.

There is a long tradition of whistleblower disclosure to the media on the basis that sunlight is the best disinfectant ${ }^{34}$ - especially if there is no-one else to turn to. Disclosure to the media must be promoted and protected.

The importance of protecting media disclosure is illustrated by heroic disclosures over the years such as the disclosures of the Pentagon Papers, disclosures which may have helped to change the course of history by contributing to US public disapproval of the Vietnam war. Former US

'an investigating authority' as defined in the Protected Disclosures Act 1994 (NSW) s 4 para (c). The Auditor-General is not a 'public officer' for the purposes of the Public Interest Disclosures Act 2002 (Tas) s 4(2).

${ }^{31}$ For example, Auditor-General Victoria, Whistleblowers legislation, available at $<$ http://www.audit.vic.gov.au/abt whistle blowers.html $>$ at February 6, 2008.

${ }^{32}$ Many whistleblowers have reported dissatisfaction with these bodies and recommend against using them': Whistleblowing and the suppression of dissent, available at $<\mathrm{http} / /$ www.uow.edu.au/arts/sts/bmartin/dissent/contacts $>$ at February 6, 2008).

${ }^{33}$ Protected Disclosures Act 1994 (NSW) ss 10, 12A, 12C; the Qld Crime and Misconduct Commission is a 'public sector entity' to receive a 'public interest disclosure' (Whistleblowers Protection Act 1994 (Qld) s 25; Sch 5, s 2(1)(i)); the Corruption and Crime Commission in WA is a 'proper authority' to receive a public interest disclosure (Public Interest Disclosure Act 2003 (WA) s 5(3)(a). Overseas, eg, the Independent Commission Against Corruption (Korea). Research indicates that $100 \%$ of journalists in NSW support ICAC and that $97 \%$ believed ICAC to be useful in exposing corruption: Stephanie Cook and Lisa Zipparo, NSW Journalists: What do they know about Corruption and the ICAC? (1999), available at $<$ http://www.icac.nsw.gov.au/files/html/pub2_17r.htm> at February 6, 2008.

${ }^{34}$ Justice Louis Brandeis, Other People's Money, and how the Bankers Use It (1914). 
defence department employee, Daniel Ellsberg disclosed to The New York Times and The Washington Post a confidential study 'History of the U.S. Decision-making Process on Vietnam Policy' which set out the US government's true negative assessment of the then war in Vietnam. Ellsberg was ultimately arrested and harassed for allegedly compromising the national security, but the US government did not succeed in its attempt to stop publication. $^{35}$

Only the Protected Disclosures Act 1994 (NSW) s 8(1)(d), with the conditions in s 19(1), provides for whistleblower disclosure to a 'journalist', defined in s 4 as a 'person engaged in the occupation of writing or editing material intended for publication in the print or electronic news media'. Disclosure to a journalist may be a fallback for the whistleblower, who has disclosed to the relevant authority, and the authority must have decided not to investigate, or must have failed to complete the investigation within six months, or decided to take no action, or failed to notify the whistleblower. This provides an excellent outside control for the whistleblower.

The Employment Rights Act 1996 (UK) sets out the circumstances in which other disclosures, including those to the media, may be protected. ${ }^{36}$ Such disclosures must meet three tests to be protected. The first test (s 43G(1)(a)(c)) deals with the evidence and motive of the whistleblower. The second test (s 43G(2)) sets out three preconditions, one of which must be met if the disclosure is to be subject to protection. The third test for a protected disclosure is that the disclosure must be reasonable in all the circumstances (s $43 \mathrm{G}(1)(\mathrm{e})$ and (3)).

\section{$4 \quad$ Whistleblower disclosure to members of parliament}

The democratic process should promote disclosure and debate under parliamentary privilege, and this should be enhanced by whistleblower protection for disclosure to a member of parliament (MP). One's elected representative should be a natural person to make a disclosure to because the representative can speak on behalf of the constituent and expose without fear or favour under parliamentary privilege. Whistleblower disclosure to

\footnotetext{
${ }^{35}$ New York Times $v$ United States 403 US 713; 29 LEd 2d 822 (1971).

${ }^{36}$ Employment Rights Act 1996 (UK), Part IVA (Protected Disclosures, ss 43A-43L), noted above $\mathrm{n} 8$.
} 
members of parliament should be in the new model, to promote disclosure and debate under parliamentary privilege.

So far, only New South Wales provides for a whistleblower to make a protected disclosure to a member of parliament. ${ }^{37}$ Queensland's Whistleblowers (Disclosure to Member of Parliament) Amendment Bill 2006 (Qld) was passed on 20 March 2007 to amend the Whistleblower Protection Act 1994 (Qld) to protect public interest disclosures made to a member of the Legislative Assembly. ${ }^{38}$

\section{$5 \quad$ Whistleblower disclosure to the Ombudsman}

Most jurisdictions specifically provide for whistleblower disclosure to the Ombudsman as an 'appropriate authority'. 39

\section{$6 \quad$ Whistleblower disclosure to police}

It would be natural for a whistleblower to want to report wrongdoing to law enforcement officers. Illegal activity can be disclosed to the police as an 'appropriate authority'. 40

\footnotetext{
${ }^{37}$ Protected Disclosures Act 1994 (NSW) s 8(1)(d), if the conditions in s 19 are fulfilled - that the whistleblower has first made disclosure to the relevant investigating authority or public authority and the disclosure has not been acted upon. Some jurisdictions provide for disclosure of information relating to members of parliament to the Speaker, Presiding Officer, etc: see eg, Whistleblowers Protection Act 1993 (SA) s 5(4)(f); Public Interest Disclosures Act 2002 (Tas) s 7(4); Whistleblowers Protection Act 2001 (Vic) s 6(2)).

38 The Queensland government approved a three-year review of the Whistleblowers Protection Act 1994 (Qld) in 2004 in response to the Parliamentary Crime and Misconduct Committee's Three Year Review of the Crime and Misconduct Commission (Report No 64). The review included consideration of the recommendations made about whistleblower protection in the reports of the Queensland Health Systems Review (Forster Report) and the Queensland Public Hospitals Commission of Inquiry (Davies Report).

${ }^{39}$ See eg Whistleblowers Protection Act 1993 (SA) s 5(4)(g); a 'proper authority' (Public Interest Disclosure Act 1994 (ACT) s 13) or a person to whom disclosure may be made (Public Interest Disclosures Act 2002 (Tas) s 7(1)(a); Whistleblowers Protection Act 2001 (Vic) s 6(1)).

${ }^{40}$ For example, Whistleblowers Protection Act 1993 (SA) s 5(4)(a).
} 


\section{$7 \quad$ Whistleblower disclosure about police}

Some jurisdictions have specialised bodies to handle whistleblower disclosure about police. For example, the Police Integrity Commission in New South Wales was established in 1996 as a body independent of the police service to deal with corruption in the State Police. ${ }^{41}$ Some jurisdictions provide that disclosure to the police about police misconduct should be made to the Commissioner of Police. ${ }^{42}$ Unfortunately, there is consistent evidence across jurisdictions that police will not whistleblow about police misconduct as the likelihood of retaliation is high, and that police misconduct will only be disclosed after there has been whistleblowing to an outside authority. ${ }^{43}$

These different agencies and personnel dealing with the police will have amassed experience and expertise in their different areas. This article supports some coordination among the existing integrity agencies in a 'cooperative ${ }^{44}$ manner in areas such as whistleblower management, monitoring and support, investigations, investigation of reprisals, prosecutions and compensation, and coordination of research and policy.

\section{Who CAN THE WhISTLEBLOWER MAKe PROTECTED DISClosures ABOUT? PUBLIC BODIES, PRIVATE INDIVIDUALS AND CONTRACTORS}

The Australian legislation provides a wide range of agencies which can be the subject of a protected whistleblower disclosure. Three states demonstrate

\footnotetext{
${ }^{41}<$ http://www.pic.nsw.gov.au $>$ at February 62008.

${ }^{42}$ Eg Public Interest Disclosures Act 2002 (Tas) s 7(2). In Queensland, certain police misconduct can be investigated by the Ombudsman: Whistleblowers Protection Act 1994 (Qld) ss 26, 27. South Australia provides for disclosure to the police:

Whistleblowers Protection Act 1993 (SA), s 4(d) ('public officer'). Tasmania provides for disclosure about the police to be made to the Commissioner of Police (Public Interest Disclosures Act 2002 (Tas) s 7(2)), and for disclosure about the Commissioner of Police to be made to the Ombudsman: Public Interest Disclosures Act 2002 (Tas) s 7(3).

${ }^{43}$ Fergus Shiel, 'Whistleblower sues Commissioner for Damages', The Age, April 17, $2006<\mathrm{http}$ //www.theage.com.au/news/national/whistleblower-sues-commissioner-fordamages/2006/04/16/1145126008830.html > at April 10, 2007); Roberta Ann Johnson, 'Whistleblowing and the police', (2005) 3 Rutgers University J Law and Urban Pol 74.

${ }^{44}$ Compare the former Commonweath/states co-operative scheme for corporate regulation (1982-1998), and the current co-operative scheme for consumer credit regulation.
} 
best practice and permit disclosure about every type of official including all parliamentarians and judicial officers. ${ }^{45}$ For example, the Public Interest Disclosure Act 2003 (WA) defines 'public interest information' to mean information regarding a 'public authority', a 'public officer' or a 'public sector contractor' (s 3). The definition of 'public authority' in s 3(1) is limited to ('means') seven categories including a department of the public service, a public organisation and local government, which would include a government-owned corporation.

\section{A Bodies performing public official functions}

There are differences in defining which bodies perform public official functions. Each jurisdiction treats agencies such as the Special Broadcasting Service (SBS, Australia's multicultural and multilingual public broadcaster), Tabcorp (gambling at the TAB) and privatised railways differently.

For example, the Public Interest Disclosure Act 1994 (ACT) refers to a 'government agency' which is defined in s 3 to mean an administrative unit, a Territory instrumentality or a statutory office-holder and its staff. The Public Interest Disclosure Bill 2006 (ACT) proposes to replace this with the even wider 'government entity' (cl 9) and 'government official' (cl 10).

The Protected Disclosures Act 1994 (NSW) includes as 'public authority' any public authority whose conduct may be investigated by an 'investigating authority', defined to include the Auditor-General and Independent Commission Against Corruption (ICAC). The Whistleblowers Protection Act 1994 (Qld) ss 16 and 17 provide that a public officer may disclose official misconduct and maladministration generally - which would catch bodies performing public official functions. In addition, s 17 provides that a public officer may disclose negligent or improper management affecting 'public sector entities', defined in Sch 5 s 2 to include commissions, authorities, offices, corporations or instrumentalities established under an Act or under state authorisation for a public or state purpose. 'Public authority' in the Public Interest Disclosure Act 2003 (WA) s 3 means inter alia a department of the public service, a public organisation, non-SES organisation, local government, a body established for a public purpose and a body established by the government.

${ }^{45}$ Queensland, South Australia and Western Australia. 


\section{B State 'public official'}

There are also big differences in who is a state 'public official' to whom disclosures may be made.

The definitions of 'public officer' in South Australia, Victoria and Western Australia are based on a person employed in the public service, with extensions to local government etc. ${ }^{46}$ In the Queensland and Tasmanian Acts, 'public officer', an officer of a public sector entity, is not the subject of the disclosure, but the person who may disclose under the Act. ${ }^{47}$

Some Acts, such as the Act in the ACT, extend 'public official' beyond an officer or employee of a government agency to a person employed by, or a person authorised to perform functions on behalf of, the territory government - such as a private contractor to the government. ${ }^{48}$

\section{Local government}

Local government has had at different times a documented bad reputation for incompetence, corruption, insider land deals and so forth. ${ }^{49}$

Whistleblower laws provide an avenue for disclosure about serious and substantial waste in local government, ${ }^{50}$ and for the reporting of local council

${ }^{46}$ Whistleblowers Protection Act 1993 (SA) s 4; Whistleblowers Protection Act 2001 (Vic) s 3; Public Interest Disclosure Act 2003 (WA) s 3.

${ }^{47}$ Whistleblowers Protection Act 1994 (Qld) Part 3; Public Interest Disclosures Act 2002 (Tas).

${ }^{48}$ Public Interest Disclosure Act 1994 (ACT) s 3 ('public official').

${ }^{49}$ History, and not only recent history, abounds with reports of 'land deals', secret rezonings, secret commissions, and the dismissal of local councils. For example, the Local Government Amendment (Discipline) Act 2004 (NSW) sets out standards of behaviour for local councillors and council staff in the Model Code of Conduct for Local Councils in NSW. In NSW, the Independent Commission Against Corruption (ICAC) can investigate local councils.

${ }^{50}$ See eg disclosure by a 'public official' to the Director-General of Local Government: Protected Disclosures Act 1994 (NSW) s 12B. The Whistleblowers Protection Act 1994 (Qld) authorises a 'public officer' to disclose negligent or improper management about inter alia a 'public sector entity', defined in Sch 5 s 2 to include 'a local government'. The Whistleblowers Protection Act 1993 (SA) includes as a 'public officer' 'a member of a local government body'. In the Public Interest Disclosure Act 2003 (WA), para (d) of 'public authority' includes a local government. 
staff, including councillors, who succumb to temptation by accepting incentives and bribes to facilitate the approvals process and so forth. ${ }^{51}$ Some whistleblower laws target the councillors themselves. ${ }^{52}$

\section{Private individuals or organisations}

There is no consistency in Australian whistleblowing laws regarding whistleblowing on the conduct of private individuals or organisations, and legislation in only three jurisdictions protects disclosure about the conduct of private individuals or organisations. ${ }^{53}$

By inference, some of the other whistleblower statutes provide for reporting by public officials of the conduct of private individuals. ${ }^{54}$ Equally 'corrupt conduct' in the Tasmanian Act includes 'conduct of a person (whether or not a public officer) ${ }^{, 55}$ 'Corrupt conduct' in s 3 of the Public Interest Disclosure Act 1994 (NSW) incorporates the meaning in the Independent Commission

\footnotetext{
${ }^{51}$ For example, South Australia provides for disclosure to a responsible officer of the relevant local government body (Whistleblowers Protection Act 1993 (SA) s 5(4)(i)); Tasmania provides for disclosure to the general manager of a council regarding an employee of that council (Public Interest Disclosures Act 2002 (Tas) s 3 'public body', para (b)); para (e) of 'public officer' in Public Interest Disclosures Act 2002 (Tas) and Whistleblowers Protection Act 2001 (Vic) s 3 include an employee of a municipal council; para (h) of 'public officer' in Public Interest Disclosure Act 2003 (WA) s 3 includes an employee of a 'public authority', which is in turn defined to include local government. Subsection (g) of 'public officer' in Whistleblowers Protection Act 1993 (SA) catches 'a member of a local government body'.

${ }^{52}$ For example, the Whistleblowers Protection Act 1994 (Qld) legislation authorises a 'public officer' to disclose negligent or improper management about, inter alia, a 'public sector entity', which is defined in Sch $5 \mathrm{sec} 2$ to include 'a local government'. The Whistleblowers Protection Act 1993 (SA) includes in its definition of 'public officer' 'a member of a local government body', indirectly catching local councils. The Public Interest Disclosures Act 2002 (Tas) does not expressly include local councils in the definition of 'public body', although 'the general manager of a council' is a public body in relation to an employee of the council (s 3).

${ }^{53}$ Public Interest Disclosure Act 1994 (ACT) s 4(2); Whistleblowers Protection Act 1993 (SA) s 4 'public interest information'; Whistleblowers Protection Act 2001 (Vic) para (a) of the definition of 'corrupt conduct' in s 3 refers to 'conduct of a person (whether or not by a public officer)'.

${ }^{54}$ It appears that a protected disclosure by a public official/public officer could include disclosure by a public official/public officer regarding a private person under Protected Disclosures Act 1994 (NSW) s 8; Whistleblowers Protection Act 1994 (Qld) s 8.

${ }^{55}$ Public Interest Disclosures Act 2002 (Tas) s 3 ('corrupt conduct'), para (a).
} 
Against Corruption Act 1988 (NSW), which includes in s 8(1)(a) 'conduct of a person (whether or not a public official)'.

The definition of 'public interest information' in $\mathrm{s} 3$ of the Western Australian Act excludes reporting of the actions of a private individual or organisation, unless they are a 'public sector contractor' as defined in s 3 , which means a person, person's employee or subcontractor who contracts with a public authority. ${ }^{56}$

In some jurisdictions, a 'public officer' who is the subject of disclosure includes an officer or employee of the academic staff of a university. ${ }^{57}$

Some legislation excludes certain persons and bodies from disclosure. For example, three jurisdictions exclude from the definition of 'public bodies' a court, board, tribunal or commission, and exclude as public officers persons such as judges, magistrates, the Director of Public Prosecutions (DPP), the Auditor-General, and the Ombudsman. ${ }^{58}$

\section{CONCLUSIONS}

Whistleblower protection is a complex issue, relying on legislative action in a number of areas. This analysis has reviewed just two basic questions dealt with by current public sector whistleblowing legislation in Australia: who may a whistleblower make a protected disclosure to, and about whom may they make it. The answers reveal differences and inconsistencies between existing instruments that demonstrate a clear need for reform. At present, the different approaches mean that a public official in one jurisdiction may be permitted to blow the whistle on particular matters in a particular way, and expect to receive legal protection, while for no good reason, an official in identical circumstances in another jurisdiction may not.

Inconsistencies may be understandable in laws passed a century ago, but these divergences in the relatively new public law whistleblower laws only enacted from the 1990s must be arrested and harmonised. Inconsistencies are not sensible in Australia's national economy, where an employee in one State can make a protected disclosure, but an employee in another cannot make the same disclosure. There is a need for the promised Commonwealth leadership

\footnotetext{
${ }^{56}$ Public Interest Disclosure Act 2003 (WA) s 3.

${ }^{57}$ Whistleblowers Protection Act 2001 (Vic) s 3 para (f) 'public officer'.

${ }^{58}$ Public Interest Disclosures Act 2002 (Tas) s 4; Whistleblowers Protection Act 1994 (Qld) s 8; Whistleblowers Protection Act 2001 (Vic) s 4.
} 
of the 2007 federal election to provide consistency in the threshold of who a disclosure can be made to, and what it can be about.

Fortunately, measures such as the Commonwealth private member's Bill in 2007, recent overseas precedents and the other elements of best practice identified in this article, demonstrate the potential for productive reform. In time, a more uniform national approach may also be assisted by trends towards more uniform national workplace relations laws, given that many of the basics of whistleblower protection are not unique to governments but rather concern the rights and duties that bind all employees and their employers. In the interim, however, coordinated legislative action is clearly called for, if Australia's whistleblowing laws are to play their core role in increasing confidence in the integrity and accountability of governments, in the eyes of the communities they serve. 
